\title{
Design and Microwave-Assisted Synthesis of Novel Macrocyclic Peptides Active at Melanocortin Receptors: Discovery of Potent and Selective hMC5R Receptor Antagonists
}

\author{
Paolo Grieco $\dagger, \ddagger, \S$, Minying Cai ${ }^{\dagger} \neq$, Lu Liu ${ }^{\ddagger}$, Alexander Mayorov $\ddagger$, Kevin Chandler ${ }_{\star}^{\ddagger}$ Dev \\ Trivedi $\ddagger$, Guangxin Lin $\ddagger$, Pietro Campigliall, Ettore Novellino $§$, and Victor J. Hruby ${ }^{*}, \ddagger$ \\ Department of Chemistry, University of Arizona, Tucson, Arizona 85721, Department of \\ Pharmaceutical Chemistry and Toxicology, University of Napoli "Federico II", Naples, Italy, and \\ Department of Pharmaceutical Science, University of Salerno, Fisciano, Salerno, Italy
}

\begin{abstract}
Differentiation of the physiological role of the melanocortin receptor $5 \mathrm{MC} 5 \mathrm{R}$ from that of other melanocortin receptors will require development of high affinity and selective antagonists. To date, a few synthetic antagonist ligands active at hMC5 receptor are available, but most do not have appreciable selectivity. With the aim to gain more potent and selective antagonists for the MC5R ligands, we have designed, synthesized, and pharmacologically characterized a series of alkylthioaryl-bridged macrocyclic peptide analogues derived from MT-II and SHU9119. These 20membered macrocycles were synthesized by a tandem combination using solid phase peptide synthesis and microwave-assisted reactions. Biological assays for binding affinities and adenylate cyclase activities for the hMC1R, hMC3R, hMC4R, and hMC5R showed that three analogues, compounds, $\mathbf{9}, \mathbf{4}$, and $\mathbf{7}$, are selective antagonists at the hMC5 receptor. In particular, compound 9 (PG-20N) is a selective and competitive hMC5R antagonist, with $\mathrm{IC}_{50}$ of $130 \pm 11 \mathrm{nM}$, and a pA value of 8.3, and represents an important tool for further biological investigations of the hMC5R. Compounds 4 and 7 (PG14N, PG17N) show potent and selective allosteric inhibition at hMC5R with $\mathrm{IC}_{50}$ values of $38 \pm 3 \mathrm{nM}$ and $58 \pm 6 \mathrm{nM}$, respectively. Compound 9 will be used to further investigate and more clearly understand the physiological roles played by the MC5 receptor in humans and other animals.
\end{abstract}

\section{Introduction}

The melanocortins are a group of structurally related peptides derived from proopiomelanocortin (POMC) that derive their name from their melanotropic and corticotropic activities and are comprised of adrenocorticotropic hormone (ACTH), $\alpha$-melanocyte stimulating hormone ( $\alpha-\mathrm{MSH}), \beta$-MSH, and $\gamma$-MSH. ${ }^{1,2}$ Post-translational modification of POMC by proteolytic cleavage generates many bioactive peptides, including the melanocortins, lipotropic hormone ( $\beta$-LPH), and $\beta$-endorphin. ${ }^{3}$ Melanocortins are best known for their ability to stimulate eumelanin synthesis in mammalian melanocytes and

\footnotetext{
(C) 2008 American Chemical Society

* To whom correspondence should be addressed: Tel.: 520-621-6332. Fax: 520-621-8407. E-mail: hruby@u.arizona.edu..

$\dagger$ These authors equally contributed to this paper.

†University of Arizona.

\$University of Napoli "Federico II".

"University of Salerno.

Supporting Information Available: ${ }^{1} \mathrm{H}$ NMR spectra of peptide analogues in DMSO- $d_{6}$ and the list of chemical shifts and coupling constants. This material is available free of charge via the Internet at http://pubs.acs.org.
} 
steroidogenesis in adrenocortical cells. ${ }^{4,5}$ These two bioactivities are by no means the exclusive effects of these hormones. Other effects include regulation of food intake and energy metabolism, and neuronal regeneration. ${ }^{6-9}$ Melanocortins act as endogenous antipyretic agents, and have systemic as well as peripheral anti-inflammatory effects. ${ }^{10,11}$ Melanocortins have sebotrophic effects, ${ }^{12}$ induce lipolysis, ${ }^{4}$ regulate exocrine glands, cardiac and testicular functions, ${ }^{13,14}$ natriuresis, and many others. ${ }^{15,16}$

The effects of melanocortins are mediated by activation of a family of melanocortin receptors (MCRs). The cloning of the MCR genes has led to tremendous progress in understanding the biological effects of melanocortins. So far, five MCR (MC1R, MC2R, MC3R, MC4R, and MC5R) genes have been cloned and the receptors pharmacologically characterized. ${ }^{16-23}$ The MC5R gene was the last of the melanocortin receptor gene family to be cloned. ${ }^{23,24}$ This receptor has the most sequence homology to MC4R and the least homology to MC2R. It is similar to MC1R and MC4R in its ability to respond to all melanocortins, except $\gamma$-MSH. The MC5R mRNA is expressed at high levels in the exocrine glands, such as lacrimal and Harderian glands. ${ }^{25}$ It is also expressed in skin tissues, particularly in sebaceous glands, and in skeletal muscles. The functions of MC5R are still not very well understood; they are speculated to include neuro/myotropic, gastric, and anti-inflammatory effects, and regulation of aldosterone secretion. $23,24,26,27$

In the present study we synthesized a series of novel 20-membered macrocycles formally derived from MTII and SHU9119, containing an alkylthioaryl bridge within the main ring by a tandem combination using solid phase peptide synthesis and microwave-assisted reactions. The 19 systematically modified analogues were tested in binding assays and in functional assays for cAMPa accumulation at human melanocortin receptors 1, 3, 4, and 5. The resulting compounds 4, 7, and 9 (PG14N, PG17N, and PG20N) were found to be selective and potent antagonists at the hMC5R.

\section{Chemistry. Peptide Synthesis}

Preparation of the macrocyclic peptides (Table 1) began with a series of HBTU/HOBt couplings performed using a ACT mod $348 \Omega$ synthesizer and following a conventional Fmoc approach $^{28}$ to obtain the appropriate open chain intermediates. Then, the peptides were capped with fluoronitrobenzoic acid (as indicated in Scheme 1 for compound $\mathbf{1}$ ) as previously reported.

${ }^{29}$ Before the cyclization step, the S-Trt group of the Cys residue were removed with dilute trifluoroacetic acid $\left(5 \%\right.$ in $\left.\mathrm{CH}_{2} \mathrm{Cl}_{2}\right)$ without cleavage of the peptide from the resin. At this stage, all peptides were transferred in a Milestone Ethos CombiChem microwave synthesizer (Milestone, Bergamo, Italy) to perform the macro-cyclization reactions. The nucleophilic aromatic substitution was performed by irradiation with $450 \mathrm{~W}, 50^{\circ} \mathrm{C}$, in DMF for $10 \mathrm{~min}$. These optimized conditions were suitable to provide more than $70 \%$ conversion of all linear peptides in cyclic peptide without decomposition of the products. The one-pot cyclization was easily monitored by analytical HPLC. Products isolated after cleavage from the resin with TFA were reasonably pure, as assessed by LC/MS, and characterized by analytical RP-HPLC.

\footnotetext{
aAbbreviations: Abbreviations used for amino acids and designation of peptides follow the rules of the IUPAC-IUB Commission of Biochemical Nomenclature in J. Biol. Chem. 1972, 247, 977-983. The following additional abbreviations are used: Boc, tertbutyloxycarbonyl; cAMP, adenosine 3',5'-cyclic monophosphate; DMF, $N, N$-dimethylformamide; FAB-MS, fast-atom bombardment mass spectrometry; Fmoc, 9-fluorenylmethoxycarbonyl; HOBt, $N$-hydroxybenzotriazole; HBTU, 2-(1H-benzotriazole-1-yl)-1,1,3,3tetramethyluronium hexafluorophosphate; HEPES, $N$-(2-hydroxyethyl)-piperazine- $N$ '-(2-ethanesulfonic acid); Pbf, 2,2,4,6,7pentamethyldihydrobenzo-furan-5-sulfonyl; RP-HPLC, reversed-phase high performance liquid chromatography; TFA, trifluoroacetic acid; Tris, 2-amino-2-(hydroxymethyl)-1,3-propanediol; Trt, triphenylmethyl (trityl); Cit, citrulline; Nal(2), 2-naphtylalanine; Aic, 2aminoindane-2-carboxylic acid; Hyp, hydroxyl-L-proline; Cpa, cyclopentyl-L-alanine; Paf, $p$-amino-Phe; MALDI, matrix-assisted laser desorption/ionization; Fmoc, fluorenylmethoxycarbonyl; amino acid symbols denote $L$-configuration unless indicated otherwise.
} 


\section{Results and Discussion}

The natural melanotropin hormones have relatively lower nM affinities for the hMC3-5R and are not particularly selective. ${ }^{16}$ Elucidation of the physiological role of the melanocortin receptor 5 will require development of high affinity and selective hMC5R antagonists. To date only a few synthetic ligands that are antagonist for hMC5 receptor are available and even those are not very selective. ${ }^{30} \mathrm{We}$ chose a cyclic lactam heptapeptide SHU9119, Ac-Nle ${ }^{4}$-cyclo $\left(\right.$ Asp $^{5}$-His ${ }^{6}-\mathrm{DNal}\left(2^{\prime}\right)^{7}-\mathrm{Arg}^{8}-\mathrm{Trp}^{9}$-Lys $\left.{ }^{10}\right)-\mathrm{NH}_{2}, 30$ a highly potent hMC3/4R antagonist and an agonist at melanocortin receptors 1 and 5 , as the starting template for the development of more selective hMC5R antagonists described in this report. Thus, with the aim to discover new potent and selective ligands at hMC5R, we designed and synthesized a series of 20-membered macrocyclic peptides in which the structures conserved the melanocortin core sequence His$\mathrm{Phe} / \mathrm{Nal}\left(2^{\prime}\right)$-Arg-Trp (Table 1). Macrocyclic peptides containing a cystine bridge have been the subject of considerable study. ${ }^{31}$ In fact, various kinds of macrocycles often have improved pharmacokinetic and conformational properties relative to their cognate peptides. ${ }^{32}$

A tandem combination was employed using solid phase peptide synthesis and microwaveassisted reaction to perform macrocyclization reactions to prepare peptidomimetics of the type shown in Figure 1. The application of microwave technology to speed up the synthesis of biologically significant molecules on solid support is of great value for library generation ${ }^{33}$ and it has recently been recognized as a useful tool for drug-discovery program. Recently, we have demonstrated that microwave irradiation combined with the solid-phase peptide synthesis represents a powerful technique for accelerating thermal organic reactions to perform macrocyclization reactions. ${ }^{29}$

In this study we prepared a number of melanotropin analogues in which 2-fluoro-5nitrobenzoic acid was used for the macro-cyclization reaction. 2-Fluoro-5-nitro benzoic acid is a useful electrophile for nucleophilic aromatic substitution reactions (SNAr) and has been used in several solid phase syntheses for various purposes. ${ }^{34}$ The macrocyclization step, carried out by our methodology, was performed in only $10 \mathrm{~min}$ compared to the conventional thermal heating, performed with potassium carbonate in DMF for $20 \mathrm{~h}$ and using identical stoichiometry. The macrocyclizations were performed between positions 5 and 10 of the peptide as in MTII, ${ }^{35}$ which was chosen as a reference compound. Thus, conserving the sequence His-Phe-Arg-Trp is important, which is responsible for biological activities. All synthesized compounds were evaluated for their binding affinities to the human melanocortin receptors 1, 3, 4, and 5 in competitive binding assays using the radiolabeled ligand [ $\left.{ }^{125} \mathrm{I}\right]-\mathrm{NDP}$ $\alpha$-MSH and for their agonist potency in cAMP assays employing the HEK293 cells expressing those receptors. All the data is compiled in Table 1.

The primary intent of the current study was to examine alkylthioaryl-type macrocyclization as an approach toward development of MT-II analogues with enhanced receptor selectivity. MCMM-low mode/OPLS-2005 simulations revealed that the 3D structure of analogue 1 significantly deviates from that of the superagonist MT-II (Figure 2), displaying a type I $\beta$-turn spanning the $\mathrm{Arg}^{8}-\mathrm{Trp}^{9}$ residues compared to type II $\beta$-turn between the $\mathrm{His}^{6}{ }_{\text {-р }}-\mathrm{Phe}^{7}$ residues in MT-II. ${ }^{36}$ Such a significant change in the peptide backbone fold may stem from the apparent face-to-face aromatic stacking interactions between the electron-rich indole ring of $\operatorname{Trp}^{9}$ and the electron-deficient aromatic linker (Figure 2). This also may result in steric crowding of the Trp ${ }^{9}$, which can be expected to strongly influence the biological activity of the peptides derived from this template. Interestingly, despite these structural deviations from the parent peptide MT-II, analogue 1 exhibited potent full agonist activities at all four melanocortin receptor subtypes. On the other hand, replacement of $\mathrm{His}^{6}$ with conformationally constrained hydrophobic amino acids Cha and Pro produced analogues $\mathbf{4}$ and $\mathbf{7}$, respectively, 3D structures of which showed minimal differences with the structure of analogue 1 (Figure 3). However, 
biological evaluation of these peptides revealed substantially diminished binding affinities and agonist potencies at the human melanocortin receptors 1,3 , and 4 , but good binding affinity to the $\mathrm{hMC} 5 \mathrm{R}\left(\mathrm{IC}_{50}=38\right.$ and $58 \mathrm{nM}$, respectively) was retained, thus making these two compounds potent and quite selective hMC5R antagonists. $\mathrm{pA}_{2}$ value assay studies showed that both analogues $\mathbf{4}$ and $\mathbf{7}$ are allosteric inhibitors of hMC5R. These findings suggest an essential role for $\mathrm{His}^{6}$ for potent full agonist activity of the peptides derived from this template, which sets it apart from other previously reported cyclic $\alpha$ - and $\gamma$-MSH templates that have been demonstrated to have no such structural requirement for $\mathrm{His}^{6}{ }^{6}{ }^{37}$ The $\beta$-turn position shift observed in our molecular modeling experiments may prove to be highly beneficial as another approach for development of highly selective melanocortin receptor agonists and antagonists. Subsequently, we synthesized a series of compounds (2-19, Table 1) where we performed modifications at positions $6^{-9}$ by replacing with several different amino acids to obtain a rational SAR study.

The compounds 2-7 differ from 1 only at position 6, where His has been replaced with Aic, Cpa, Cha, DPro, Hyp, and Pro residues. Compound $\mathbf{2}$, having an Aic residue in position 6, was found to be a weak agonist at the $\mathrm{hMC} 1$ receptor and inactive at $\mathrm{hMC} 3$ and $\mathrm{hMC} 4$ receptors but an antagonist at the hMC5R $\left(\mathrm{IC}_{50}=565 \mathrm{nM}\right)$. Compound 3 , with a Cpa residue in position 6 , and compound 6, with a Hyp residue in the same position, were found to be inactive at all melanocortin receptors tested. On the other hand, compound $\mathbf{5}$, with a DPro residue, resulted in a weak antagonist at the $\mathrm{MC} 1$ receptor. Surprisingly, in this series of macrocyclic derivatives, the compounds $\mathbf{4}$ and $\mathbf{7}$ had potent antagonist activity at the hMC5 receptor. In fact, compound 4 showed low affinity and potency as an agonist at the $\mathrm{MC} 1$ and $\mathrm{MC} 3$ receptors $\left(\mathrm{IC}_{50}=>2000\right.$ and $>1000$, respectively) but high potency as antagonist at the MC5R $\left(\mathrm{IC}_{50}=38 \mathrm{nM}\right)$. Interestingly, compound 7 was found to be a potent and selective antagonist at the hMC5R $\left(\mathrm{IC}_{50}=58 \mathrm{nM}\right)$ but a weak agonist $\left(\mathrm{IC}_{50}=380 \mathrm{nM}\right)$ at the $\mathrm{hMC} 3 \mathrm{R}$, and inactive at the other two melanocortin receptors. The additional compounds 8-11 were modified in position 7 where the $D$ Phe residue has been replaced with $\mathrm{Nal}\left(2^{\prime}\right), D \mathrm{Nal}\left(2^{\prime}\right)$, Cit, and Paf. Compound 8 was a poor agonist at the hMC1R and inactive at the hMC4R, but it was found to be a weak antagonist at the $\mathrm{hMC} 3$ and the $\mathrm{hMC} 5$ receptors $\left(\mathrm{IC}_{50}=190\right.$ and $760 \mathrm{nM}$, respectively). Figure 3 shows a stereoview of the superimposed global minimum of compounds $\mathbf{4}, \mathbf{7}$, and peptide 1. The compounds $\mathbf{4}$ and $\mathbf{7}$ are highly selective hMC5R antagonists (Table 1). The aromatic linker is stacked with the indole ring of $\operatorname{Trp}^{9}$ or $\mathrm{Xaa}^{9}$. This caused the $\operatorname{Trp}^{9}$ to take a new conformation that is not in the $\beta$ turn region of MTII, which has been proposed ${ }^{36}$ as critical for binding to the $\mathrm{hMC} 1 \mathrm{R}, \mathrm{hMC} 3 \mathrm{R}$ and $\mathrm{hMC}$. Thus, our new ligands are found to have selective binding to the hMC5R. In earlier observations, ${ }^{38}$ we obtained hMC $3 R$ and hMC4R antagonists and hMC5R agonists when $\mathrm{His}^{6}$ was replaced with $\mathrm{Pro}^{6}$ or with many similar conformationally restricted amino acids. This is in contrast with the present study where 20membered macrocycle peptides 4,7 , and 9 produced hMC5R selective antagonists, which are weak hMC3R agonists and totally inactive at the hMC4R.

Compound 9 in which $D \mathrm{Nal}\left(2^{\prime}\right)$ residue was replaced with its isomer $L \mathrm{Nal}\left(2^{\prime}\right)$ resulted in a weak agonist at the hMC3R, no activity at the hMC4R, and a very weak antagonist activity at the hMC1R. However, 9 is a potent, selective, and competitive antagonist at the hMC5R $\left(\mathrm{IC}_{50}=130 \mathrm{nM}\right)$ with a $\mathrm{pA}_{2}$ value of 8.3. Compounds $\mathbf{1 0}$ and $\mathbf{1 1}$, where the $D P$ Pe residue was replaced by $\mathrm{Paf}$ and Cit, respectively, were completely inactive at all melanocortin receptors tested. These results are in line with previous results showing the importance of an aromatic residue in position 7. Compounds 12-14 in which Arg residue was replaced by other basic amino acids such as Lys, DArg, and Orn were completely inactive. These results represent an additional demonstration that modification of the Arg residue in position 8 can be highly detrimental for biological activity. Finally, we explored position 9, replacing the Trp residue with $D \mathrm{Nal}\left(2^{\prime}\right), \mathrm{Nal}\left(2^{\prime}\right), D$ Phe, Phe, and $D$ Trp residues. Compound 15 (with $\left.D \mathrm{Nal}\left(2^{\prime}\right)^{9}\right)$ showed a weak agonist activity at the hMC3R but was inactive at all other receptors. Compound $\mathbf{1 6}$ 
with $\mathrm{Nal}\left(2^{\prime}\right)^{9}$ was a good agonist at the $\mathrm{hMC} 1 \mathrm{R}$ and a weak agonist at $\mathrm{hMC} 3 \mathrm{R}\left(\mathrm{IC}_{50}=180\right.$ and $610 \mathrm{nM}$, respectively) but was inactive at the hMC4R and a weak antagonist at the hMC5R $\left(\mathrm{IC}_{50}=340 \mathrm{nM}\right)$. Compounds 17 and 18 containing Phe and DPhe residues, respectively, in position 9 were inactive at all melanocortin receptors. Finally, compound 19 containing a $D \operatorname{Trp}$ in position 9 was a weak agonist at the hMC1R and totally inactive at all other melanocortin receptors.

In conclusion, we have designed, synthesized, and biologically evaluated new 20-membered macrocyclic peptidomimetics with interesting bioactivities. The binding affinity and adenylate cyclase activity assays of these novel macrocycles at human melanocortin receptors showed that three of the new $\alpha-\mathrm{MSH}$ analogues act as selective antagonists toward the human melanocortin-5 receptor. In particular, we have identified compounds 4, 7, and $\mathbf{9}$, which represent important new tools to investigate the physiological role played by hMC5 receptor in vivo. The identification of these new ligands was enabled by the versatile and powerful implementation of solid-phase peptide strategy and microwave-assisted synthesis. Further applications of this methodology will be investigated to perform the synthesis of selective ligands at all melanocortin receptors.

\section{Experimental Section}

\section{Materials}

$N^{\alpha}$-Fmoc-protected amino acids and resin were purchased from Advanced ChemTech (Louisville, KY). HBTU and HOBt were purchased from Quantum Biotechnologies (Montreal, Quebec, Canada). For the $N^{\alpha}$ Fmoc-protected amino acids, the following side chain protecting groups were used: $\operatorname{Cys}(\operatorname{Trt}), \operatorname{Arg}\left(N^{\prime}\right.$-Pbf $), \operatorname{His}\left(N^{\text {im }}-\operatorname{Trt}\right)$, and $\operatorname{Trp}\left(N^{\text {in }}-\right.$ Boc $)$. All protected amino acid derivatives were analyzed for purity by thin-layer chromatography before use. Peptide synthesis solvents, reagents, as well as $\mathrm{CH}_{3} \mathrm{CN}$ for $\mathrm{HPLC}$ were reagent grade and were acquired from commercial sources and used without further purification unless otherwise noted. TLC was done on Analtech, Inc. (Newark, DE) silica gel $60 \mathrm{~F}_{254}$ plates using the following solvent systems: (A) 1-butanol/acetic acid/pyridine/water (5:5:1:4); (B) ethyl acetate/pyridine/acetic acid/water (5:5:1:3); (C) upper phase of 1-butanol/acetic acid/water (4:1:1). The peptides were detected on the TLC plates using iodine vapor. Amino acid analyses were carried out using a Pico-Tag work station (Waters-Millipore, Waltham, MA). Peptide structures were confirmed by MALDI-TOF MS analyses. The purity of the finished peptides was checked by analytical RP-HPLC using a Shimadzu model CL-10AD VP system with a built-in diode array detector. In all cases, the purity of the finished peptides was greater than $95 \%$ as determined by these methods. The analytical data for the peptide is given in Table 2 .

\section{General Method for Peptide Synthesis and Purification}

The protected peptide resins used to make the cyclic melanotropins were prepared using $0.5 \mathrm{~g}$ of Rink amide resin $\left(0.7 \mathrm{mmol}\right.$ of $\mathrm{NH}_{2} / \mathrm{g}$ of resin) by first coupling $\mathrm{N}^{\alpha}$-Fmoc-Cys(Trt)-OH to the resin previously deprotected by a $25 \%$ piperidine solution in DMF for $30 \mathrm{~min}$. In this strategy automated solid phase synthesis was performed on the Advanced ChemTech ACT $348 \Omega$ instrument. The following protected amino acids were then added stepwise $\mathrm{N}^{\alpha}$-Fmoc$\operatorname{Trp}\left(\mathrm{N}^{\text {in }}\right.$-Boc)-OH, $\mathrm{N}^{\alpha}-\mathrm{Fmoc}-\mathrm{Arg}\left(\mathrm{N}^{\gamma}-\mathrm{Pbf}\right)-\mathrm{OH}, \mathrm{N}^{\alpha}$-Fmoc-DNal(2')-OH, Fmoc-DPhe-OH, $\mathrm{N}^{\alpha}{ }_{-}$ Fmoc-His(Nim-Trt)-OH or $\mathrm{N}^{\alpha}$-Fmoc-Xaa-OH. Each coupling reaction was accomplished using a 3-fold excess of amino acid with HBTU (HOBt) in the presence of diisopropylethyl amine (DIEA). The $\mathrm{N}^{\alpha}$-Fmoc protecting groups were removed by treating the protected peptide resin with $25 \%$ piperidine solution in DMF twice $(1 \times 5 \mathrm{~min}$ and $1 \times 25 \mathrm{~min})$. The peptide resin was then washed three times with DMF and the next coupling step was then initiated in a stepwise manner. All reactions were done under a nitrogen atmosphere. Then the linear peptide sequence was capped with fluorobenzoic acid (as indicated in Scheme 1 for compound 1). 
Before the cyclization step, the S-Trt group of Cys residue was removed with dilute trifluoroacetic acid (5\% in $\mathrm{CH}_{2} \mathrm{Cl}_{2}$ ), without cleavage of the peptidomimetic from the resin. At this stage all peptides were transferred in a Milestone Ethos CombiChem microwave synthesizer to perform the macrocyclization reactions. The nucleophilic aromatic substitution was performed by irradiation with $450 \mathrm{~W}, 50{ }^{\circ} \mathrm{C}$, in DMF for $10 \mathrm{~min}$. These optimized conditions were suitable to provide more than $70 \%$ conversion of all linear peptides in cyclic peptide without decomposition of the products. The one-pot cyclization was easily monitored by analytical HPLC. In particular, all reactions were carried out in vessels of $4 \mathrm{~mL}$ volume, using DMF as solvent. In all irradiation experiments, rotation of the rotor, irradiation time, temperature, and power were monitored with the "easyWAVE" software package.

Temperature was monitored with the aid of an optical fiber inserted into one of the reaction containers. Once $50{ }^{\circ} \mathrm{C}$ was reached, the reaction mixture was held at this temperature for 10 min and then cooled rapidly to room temperature. The reaction vessels were opened and the contents were poured into a separating funnel. The compounds were washed and subjected to the final cleavage from the resin. The resin was removed by filtration and the crude peptide recovered by precipitation using cold anhydrous ethyl ether to give a white powder, which was purified by HPLC on a C18-bonded silica column (Vydac 218TPP1010, $1.0 \times 25 \mathrm{~cm}$ ), eluting with a linear gradient of acetonitrile in aqueous $0.1 \%$ TFA. The products were obtained by lyophilization of the appropriate fractions after removal of the acetonitrile by rotary evaporation. Analysis by analytical HPLC and TLC (three solvents) showed the peptides to be pure ( $>98 \%$; Table 2$)$. The structures were further confirmed by high resolution mass spectroscopy (Table 2) and amino acid analysis.

\section{Biological Activity Assays. Receptor Binding Assay}

Competition binding experiments were carried out using whole HEK293 cells stably expressing human MC1, MC3, MC4, and MC5 receptors. HEK293 cells transfected with hMCRs ${ }^{39}$ were seeded on 96 -well plates $48 \mathrm{~h}$ before assay (50000 cells/well). For the assay, the cell culture medium was aspirated and the cells were washed once with a freshly prepared MEM buffer containing 100\% minimum essential medium with Earle's salt (MEM, GIBCO) and $25 \mathrm{mM}$ sodium bicarbonate. Next, the cells were incubated for $40 \mathrm{~min}$ at $37^{\circ} \mathrm{C}$ with different concentrations of unlabeled peptide and labeled $\left[{ }^{125} \mathrm{I}\right]-\left[\mathrm{Nle}^{4}, D-\mathrm{Phe}^{7}\right]-\alpha-\mathrm{MSH}$ (Perkin-Elmer Life Science, $20000 \mathrm{cpm} /$ well, $33.06 \mathrm{pM}$ ) diluted in $125 \mu \mathrm{L}$ of freshly prepared binding buffer containing 100\% MEM, $25 \mathrm{mM}$ HEPES (pH 7.4), $0.2 \%$ bovine serum albumin, $1 \mathrm{mM}$ 1,10-phenanthrolone, $0.5 \mathrm{mg} / \mathrm{L}$ leupeptin, $200 \mathrm{mg} / \mathrm{L}$ bacitracin. The assay medium was subsequently removed, the cells were washed once with basic medium, and then lysed by the addition of $100 \mu \mathrm{L}$ of $0.1 \mathrm{M} \mathrm{NaOH}$ and $100 \mu \mathrm{L}$ of $1 \%$ Triton X-100. The lysed cells were transferred to $12 \times 75 \mathrm{~mm}$ borosilicate glass tubes, and the radioactivity was measured by a Wallac 1470 WIZARD Gamma Counter.

\section{Adenylate Cyclase Assay}

HEK 293 cells transfected with human melanocortin receptors ${ }^{39}$ were grown to confluence in MEM medium (GIBCO) containing 10\% fetal bovine serum, 100 units $/ \mathrm{mL}$ penicillin and streptomycin, and $1 \mathrm{mM}$ sodium pyruvate. The cells were seeded on 96 -well plates $48 \mathrm{~h}$ before assay (50000 cells/well). For the assay, the cell culture medium was removed and the cells were rinsed with $100 \mu \mathrm{L}$ of MEM buffer (GIBCO). An aliquot $(100 \mu \mathrm{L})$ of the Earle's balanced salt solution with $0.5 \mathrm{mM}$ isobutylmethylxanthine (IBMX) was placed in each well along for $1 \mathrm{~min}$ at $37^{\circ} \mathrm{C}$. Next, aliquots $(25 \mu \mathrm{L})$ of melanotropin peptides of varying concentration were added, and the cells were incubated for $3 \mathrm{~min}$ at $37^{\circ} \mathrm{C}$. The reaction was stopped by aspirating the assay buffer and adding $60 \mu \mathrm{L}$ ice-cold Tris/EDTA buffer to each well, then placing the plates in a boiling water bath for $7 \mathrm{~min}$. The cell lysates were then centrifuged for $10 \mathrm{~min}$ at $2300 \mathrm{~g}$. A $50 \mu \mathrm{L}$ aliquot of the supernatant was transferred to another $96-w e l l$ plate and placed with $50 \mu \mathrm{L}\left[{ }^{3} \mathrm{H}\right]$ cAMP and $100 \mu \mathrm{L}$ protein kinase A (PKA) buffer in an ice bath for 2-3 $\mathrm{h}$. 
The PKA buffer consisted of Tris/EDTA buffer with $60 \mu \mathrm{g} / \mathrm{mL}$ PKA and $0.1 \%$ bovine serum albumin by weight. The incubation mixture was filtered through $1.0 \mu \mathrm{m}$ glass fiber filters in MultiScreen-FB 96-well plates (Millipore, Billerica, MA). The total $\left[{ }^{3} \mathrm{H}\right]$ cAMP was measured by a Wallac MicroBeta TriLux 1450 LSC and Luminescence Counter (PerkinElmer Life Science, Boston, MA). The cAMP accumulation data for each peptide analogue was determined with the help of a cAMP standard curve generated by the same method as described above. $\mathrm{IC}_{50}$ and $\mathrm{EC}_{50}$ values represent the mean of two experiments performed in triplicate. $\mathrm{IC}_{50}$ and $\mathrm{EC}_{50}$ estimates and their associated standard errors were determined by fitting the data using a nonlinear least-squares analysis, with the help of GraphPad Prism 4 (GraphPad Software, San Diego, CA). The maximal cAMP produced at $10 \mu \mathrm{M}$ concentration of each ligand was compared to the amount of cAMP produced at $10 \mu \mathrm{M}$ concentration of the standard agonist MT-II, and is expressed in percent (as \% max effect) in Table 1. The antagonist properties of the lead compounds were evaluated by their ability to competitively displace the MT-II agonist in a dose-dependent manner at four different doses of the antagonist for $10^{-10}$ to $10^{-6} \mathrm{M}$. The $\mathrm{pA}_{2}$ values were obtained using the Schild analysis method. ${ }^{40}$

\section{Data Analysis}

$\mathrm{IC}_{50}$ and $\mathrm{EC}_{50}$ values represent the mean of two experiments performed in triplicate. $\mathrm{IC}_{50}$ and $\mathrm{EC}_{50}$ estimates and their associated standard errors were determined by fitting the data using a nonlinear least-squares analysis, with the help of GraphPad Prism 4 (GraphPad Software, San Diego, CA).

\section{Computational Procedures}

Molecular modeling experiments employed MacroModel version 9.1 equipped with Maestro 7.5 graphical interface (Schrödinger, LLC, New York, NY, 2005) installed on a Linux Red Hat 9.0 system and were performed as previously described. ${ }^{37}$ Peptide structures were built into extended structures with standard bond lengths and angles, and they were minimized using the OPLS 2005 force field ${ }^{41}$ and the Polak-Ribier conjugate gradient (PRCG). Optimizations were converged to a gradient rmsd less that $0.05 \mathrm{~kJ} / \AA$ A mol or continued until a limit of 50000 iterations was reached. Aqueous solution conditions were simulated using the continuum dielectric water solvent model (GB/SA). ${ }^{42}$ Extended cutoff distances were defined at $8 \AA$ for Van der Waals, 20 for electrostatics, and 4 Å for H-bonds.

Conformational profiles of the cyclic peptides were investigated by the hybrid Monte Carlo/ Low Frequency Mode (MCMM/LMCS $)^{43}$ procedure as implemented in Macromodel using the energy minimization parameters as described above. MCMM torsional variations and Low Mode parameters were set up automatically within Maestro graphical user interface. A total of 20000 search steps were performed and the conformations with energy difference of $50 \mathrm{~kJ} /$ mol from the global minimum were saved. The superimpositions of peptide structures were performed using the $\alpha$-carbons of the core sequence -His- $D$-Phe-Arg-Trp- with $\mathrm{Xa}^{6}-\mathrm{Xb}^{7}$ $\mathrm{Xc}^{8}-\mathrm{Xd}^{9}-$.

\section{Supplementary Material}

Refer to Web version on PubMed Central for supplementary material.

\section{Acknowledgment}

This research was supported primarily by the U.S. Public Health Service, National Institute of Health, DK17420 and DA06284. We thank Erin Palmer for the $\mathrm{pA}_{2}$ values. 


\section{References}

1. Mains RE, Eipper BA. Biosynthesis of adrenocorticotropic hormone in mouse pituitary tumor cells. J. Biol. Chem 1976;251:4115-4120. [PubMed: 180015]

2. Eipper BA, Mains RE. Structure and biosynthesis of proadrenocorticotropin/endorphin and related peptides. Endocr. Rev 1980;1:1-27. [PubMed: 6262069]

3. Hadley, ME. Endocrinology. Vol. 4th edition. Prentice-Hall; Upper Saddle River, N.J.: 1996.

4. Simpson ER, Waterman MR. Regulation of the synthesis of steroidogenic enzymes in adrenal cortical cells by ACTH. Annu. Rev. Physiol 1988;50:427-440. [PubMed: 2837136]

5. Geschwind II, Huseby RA, Nishioka R. The effect of melanocyte-stimulating hormone on coat color in the mouse. Recent Prog. Horm. Res 1972;28:91-130. [PubMed: 4631622]

6. Wei F, Bruce A, Boston R, Kesterson A, Hruby VJ, Cone RD. Role of melanocortinergic neurons in feeding and the agouti obesity syndrome. Nature 1997;385:165-168. [PubMed: 8990120]

7. Krude H, Biebermann H, Luck W, Horn R, Brabant G, Grüters A. Severe early-onset obesity, adrenal insufficiency and red hair pigmentation caused by POMC mutations in humans. Nat. Genet 1998;19:155-157. [PubMed: 9620771]

8. Hinney A, Becker I, Heibult O, Nottebom K, Schmidt A, Ziegler A, et al. Systematic mutation screening of the pro-opiomelanocortin gene: identification of several genetic variants including three different insertions, one nonsense and two missense point mutations in probands of different weight extremes. J. Clin. Endocrinol. Metab 1998;83:3737-3741. [PubMed: 9768693]

9. Van Der Neut R, Hol EM, Gispen WH, Bär PR. Stimulation by melanocortins of neurite outgrowth from spinal and sensory neurons in vitro. Peptides 1992;13:1109-1115. [PubMed: 1337376]

10. Luger TA, Scholzen T, Brzoska T, Becher E, Slominski A, Paus R. Cutaneous immunomodulation and coordination of skin stress responses by a-melanocyte-stimulating hormone. Ann. N.Y. Acad. Sci 1998;840:381-394. [PubMed: 9629265]

11. Lipton JM, Catania A. Mechanisms of anti-inflammatory action of the neuroimmunomodulatory peptide a-MSH. Ann. N.Y. Acad. Sci 1998;840:373-380. [PubMed: 9629264]

12. Thody AJ, Shuster S. The pituitary and sebaceous gland activity. J. Endocrinol 1970;48:139-140. [PubMed: 4319570]

13. Tsong S-D, Phillips DM, Halmi N, Krieger DT, Bardin CW. $\beta$-Endorphin is present in the male reproductive tract of five species. Biol. Reprod 1982;27:755-764. [PubMed: 6291653]

14. Boitani C, Farini D, Canipari R, Bardin CW. Estradiol and plasminogen activator secretion by cultured rat Sertoli cells in response to melanocyte-stimulating hormones. J. Androl 1988;10:202-209. [PubMed: 2473057]

15. Lymangrover JR, Buckalew VM, Harris J, Klein MC, Gruber KA. Gamma-2MSH is natriuretic in the rat. Endocrinology 1985;116:1227-1229. [PubMed: 3971908]

16. Cone, RD. The Melanocortin Receptors. Tortura. Vol. 15. Humana Press; New Jersey: 2000. p. 551

17. Mountjoy KG, Robbins LS, Mortrud MT, Cone RD. The cloning of a family of genes that encode the melanocortin receptors. Science 1992;257:1248-1251. [PubMed: 1325670]

18. Chhajlani V, Wikberg JES. Molecular cloning and expression of the human melanocyte stimulating hormone receptor cDNA. FEBS Lett 1992;309:417-420. [PubMed: 1516719]

19. Chhajlani V, Muceniece R, Wikberg JES. Molecular cloning of a novel human melanocortin receptor. Biochem. Biophys. Res. Commun 1993;195:866-873. [PubMed: 8396929]

20. Gantz I, Konda Y, Tashiro T, Shimoto Y, Miwa H, Munzert G, et al. Molecular cloning of a novel melanocortin receptor. J. Biol. Chem 1993;268:8246-8250. [PubMed: 8463333]

21. Gantz I, Miwa H, Konda Y, Shimoto Y, Tashiro T, Watson SJ, et al. Molecular cloning, expression, and gene localization of a fourth melanocortin receptor. J. Biol. Chem 1993;268:15174-15179. [PubMed: 8392067]

22. Roselli-Rehfuss L, Mountjoy KG, Robbins LS, Mortrud MT, Low MJ, Tatro JB, et al. Identification of a receptor for gamma-melanotropin and other proopiomelanocor-tin peptides in the hypothalamus and limbic system. Proc. Natl. Acad. Sci. U.S.A 1993;90:8856-8860. [PubMed: 8415620] 
23. Gantz I, Shimoto Y, Konda Y, Miwa H, Dickinson CJ, Yamada T. Molecular cloning, expression, and characterization of a fifth melanocortin receptor. Biochem. Biophys. Res. Commun 1994;200:1214-1220. [PubMed: 8185570]

24. Labbé O, Desarnaud F, Eggerickx D, Vassart G, Parmentier M. Molecular cloning of a mouse melanocortin 5 receptor gene widely expressed in peripheral tissues. Biochemistry 1994;33:45434549. [PubMed: 8161509]

25. Chen W, Kelly MA, Opitz-Araya X, Thomas RE, Low MJ, Cone RD. Exocrine gland dysfunction in MC5-R-deficient mice: evidence for coordinated regulation of exocrine gland function by melanocortin peptides. Cell 1997;91:789-798. [PubMed: 9413988]

26. Griffon N, Mignon V, Facchinetti P, Diaz J, Schwartz JC, Sokoloff P. Molecular cloning and characterization of the rat fifth melanocortin receptor. Biochem. Biophys. Res. Commun 1994;200:1007-1014. [PubMed: 8179577]

27. Fathi Z, Iben LG, Parker EM. Cloning, expression, and tissue distribution of a fifth melanocortin receptor subtype. Neurochem. Res 1995;20:107-113. [PubMed: 7739752]

28. Atherton, E.; Sheppard, RC. Solid-Phase Peptide Synthesis: A Practical Approach. IRL Press; Oxford, U.K.: 1989.

29. Grieco P, Campiglia P, Gomez-Monterrey I, Lama T, Novellino E. Tandem solid phase peptide synthesis and microwave-assisted reaction to perform macrocyclization reactions. Synlett 2003;14:2216-2218.

30. a Hruby VJ, Lu D, Sharma SD, Castrucci A. deL. Kesterson RA, Al-Obeidi FA, Hadley ME, Cone RD. Cyclic lactam $\alpha$-melanotropin analogues of Ac-Nle4-c[Asp5,D-Phe7,Lys10] $\alpha \mathrm{MSH}(4-10)-\mathrm{NH} 2$ with bulky aromatic amino acids at position 7 show high antagonist potency and selectivity at specific melanocortin receptors. J. Med. Chem 1995;38:3454-3461. [PubMed: 7658432] b Mayorov AV, Han S-Y, Cai M, Hammer MR, Trivedi D, Hruby VJ. Effects of macrocycle size and rigidity on melanocortin receptor- 1 and -5 selectivity in cyclic lactam $\alpha$-MSH analogues. Chem. Biol. Drug Des 2006;67:329-335. [PubMed: 16784457] c Bednarek MA, MacNeil T, Tang R, Fong TM, Cabello MA, Maroto M, Teran A. Potent and selective agonists of human melanocortin receptor 5: Cyclic analogues of $\alpha$-melanocyte-stimulating hormone. J. Med. Chem 2007;50:2520-2526. [PubMed: 17455928]

31. a Mosberg HI, Hurst R, Hruby VJ, Gee K, Yamamura HI, Galligan JJ, Burks TF. Bis-penicillamine enkephalins possess highly improved specificity toward delta opioid receptors. Proc. Natl. Acad. Sci. U.S.A 1983;80:5871-5874. [PubMed: 6310598] b Sawyer TK, Hruby VJ, Darman PS, Hadley ME. [4-Half-cystine, 10 -half-cystine]- $\alpha$-melanocyte stimulating hormone: A cyclic $\alpha$-melanotropin exhibiting superagonist biological activity. Proc. Nat. Acad. Sci. U.S.A 1982;79:1751-1755. c Moore ML, Albrightson C, Brickson B, Bryan HG, Calwell N, Callahan JF, Foster J, Kinter LB, Newlander KA, Schmidt DB, Sorenson E, Stassen FL, Yim NCF, Huffman WF. Dicarbavasopressin antagonist analogs exhibit reduced in vivo agonist activity. J. Med. Chem 1988;31:1487-1489. [PubMed: 3397986] d Barker PL, Bullens S, Bunting S, Burdick JD, Chan KS, Deishe T, Eigenbrot C, Gadek TR, Gantzos R, Lapari MT, Muir CD, Napier MA, Pitti RM, Padua A, Quan C, Stanley M, Struble M, Tom JYK, Burnier JP. Cyclic RGD peptide analogs as antiplatelet antithrombotics. J. Med. Chem 1992;35:2040-2048. [PubMed: 1597855] e Virgilio AA, Ellman JA. Simultaneous solid-phase synthesis of $\beta$-turn mimetics incorporating side-chain functionality. J. Am. Chem. Soc 1994;116:11580-11581. f Mayer JP, Heil JR, Zhang J, Munson MC. An alternative solid-phase approach to C1-oxytocin. Tetrahedron Lett 1995;36:7387-7390. g Burgess K, Lim D, Bois-Choussy M, Zhu J. Rapid and efficient solid phase syntheses of cyclic peptides with endocyclic biaryl ether bonds. Tetrahedron Lett 1997;19:3345-3348. h Zhu J, Zhu J. SNAr bases macrocyclization via biaryl ether formation: Application in natural product synthesis. Synlett 1997;2:133-144.

32. Fotsch C, Kumaravel G, Sharma SK, Wu AD, Gounarides JS, Nirmale NR, Petter RC. On-resin macrocyclization of peptides via intramolecular SnAr reactions. Bioorg. Med. Chem. Lett 1999;9:2125-2130. [PubMed: 10465530] b Feng Y, Wang Z, Jin S, Burgess K. SNAr cyclizations to form cyclic peptidomimetics of $\beta$-turns. J. Am. Chem. Soc 1998;120:10768-10769. c Goldberg M, Smith L, Tamayo N, Kiselyov AS. Solid support synthesis of 14-membered macrocycles containing 4-hydroxyproline structural unit via SNAr methodology. Tetrahedron 1999;55:1388713898. d Kiselyov AS, Smith L II, Tempest P. Solid support synthesis of 14- and 17-membered macrocycles via the SNAr methodology. Tetrahedron 1999;55:14813-14822. e Ouyang X, Chen Z, Liu L, Dominguez C, Kiselyov AS. Novel and highly efficient synthesis of substituted dibenz $[b, g]$ 
1,5-oxazocines. A direct comparison of the solution versus solid-phase approach. Tetrahedron 2000;56:2369-2377. f Feng Y, Pattarawarapan M, Wang Z, Burgess K. Solid-phase SN2 macrocyclization reactions to form $\beta$-turn mimics. Org. Lett 1999;1:121-124. [PubMed: 10822547]

33. a Strohmeier GA, Kappe O. Rapid parallel synthesis of polymer-bound enones utilizing microwaveassisted solid-phase chemistry. J. Comb. Chem 2002;4:154-161. [PubMed: 11886290] b Lidstrom P, Tierney J, Wathey B, Westman J. Microwave assisted organic synthesis-a review. Tetrahedron 2001;57:9225-9283. c Finaru A, Berthault A, Besson T, Guillaumet G, Berteina-Raboin S. Org. Lett 2002;4:2613. [PubMed: 12153191] d Lew A, Krutzik PO, Hart ME, Chamberlin AR. Increasing rates of reaction: Microwave-assisted organic synthesis for combinatorial chemistry. J. Comb. Chem 2002;4:95-105. [PubMed: 11886281] e Kappe O. High-speed combinatorial synthesis utilizing microwave irradiation. Curr. Opin. Chem. Biol 2002;6:314. [PubMed: 12023111] f Coleman CM, MacElroy JMD, Gallagher JF, O'Shea DF. Microwave parallel library generation: Comparison of a conventional- and microwave-generated substituted 4(5)-sulfanyl-1H-imidazole library. J. Comb. Chem 2002;4:87-93. [PubMed: 11831886] g Larhed M, Hallberg A. Microwave-assisted high-speed chemistry: A new technique in drug discovery. Drug Discovery Today 2001;6:406-416. [PubMed: 11301285]

34. a Yu L, Lai Y, Wade JV, Coutts SM. A simple and efficient method for the syntheses of thioether cyclic peptides. Tetrahedron Lett 1998;39:6633-6636. b Mayer JP, Zhang J, Groeger S, Liu C-F, Jarosinski MA. Lanthionine macrocyclization by in situ activation of serine. J. Pept. Res 1998;51:432-436. [PubMed: 9650717] c Jiang L, Burgess K. Fluorinated and iodinated templates for syntheses of $\beta$-turn peptidomimetics. Tetrahedron 2002;58:8743-8750. d Park C, Burgess K. Facile macrocyclizations to $\beta$-turn mimics with diverse structural, physical, and conformational properties. J. Comb. Chem 2001;3:257-266. [PubMed: 11350249]

35. Al-Obeidi F, Hadley ME, Pettitt BM, Hruby VJ. Design of a new class of superpotent cyclic $\alpha-$ melanotropins based on quenched dynamic simulations. J. Am. Chem. Soc 1989;111:3413-3416.

36. Ying J, Kövér KE, Gu X, Han G, Trivedi DB, Kavarana MJ, Hruby VJ. Solution structures of cyclic melanocortin agonists and antagonists by NMR. Biopolymers 2003;71:696-716. [PubMed: 14991679]

37. Mayorov AV, Cai M, Chandler KB, Petrov RR, Van Scoy AR, Yu Z, Tanaka DK, Trivedi D, Hruby VJ. Development of cyclic $\gamma$-MSH analogues with selective hMC3R agonist and hMC3R/hMC5R antagonist activities. J. Med. Chem 2006;49:1946-1952. [PubMed: 16539382]

38. Grieco P, Lavecchia A, Cai M, Trivedi D, Weinberg D, MacNeil T, Van der Ploeg LHT, Hruby VJ. Structure-activity studies of the melanocortin peptides: Discovery of potent and selective affinity antagonists for the hMC3 and hMC4 receptors. J. Med. Chem 2002;45:5287-5294. [PubMed: 12431055]

39. Cai M, Cai C, Mayorov AV, Xiong C, Cabello CM, Soloshonok VA, Swift JR, Trivedi D, Hruby VJ. Biological and conformational study of substituted prolines in MT-II template: Steric effects leading to human MC5 receptor selectivity. J. Pept. Res 2004;63:116-131. [PubMed: 15009533]

40. Schild HO. pA, a new scale for the measurement of drug antagonism. Br. J. Pharmacol 1947;2:189206.

41. Kaminski GA, Friesner RA, Tirado-Rives J, Jorgensen WL. Evaluation and reparametrization of the OPLS-AA force field for proteins via comparison with accurate quantum chemical calculations on peptides. J. Phys. Chem. B 2001;105:6474-6487.

42. Still WC, Tempczyk A, Hawlely RC, Hendrickson T. A general treatment of solvation for molecular mechanics. J. Am. Chem. Soc 1990;112:6127-6129.

43. Kolossváry I, Guida WC. Low-mode conformational search elucidated. Application to C39H80 and flexible docking of 9-deazaguanine inhibitors to PNP. J. Comput. Chem 1999;20:1671. 

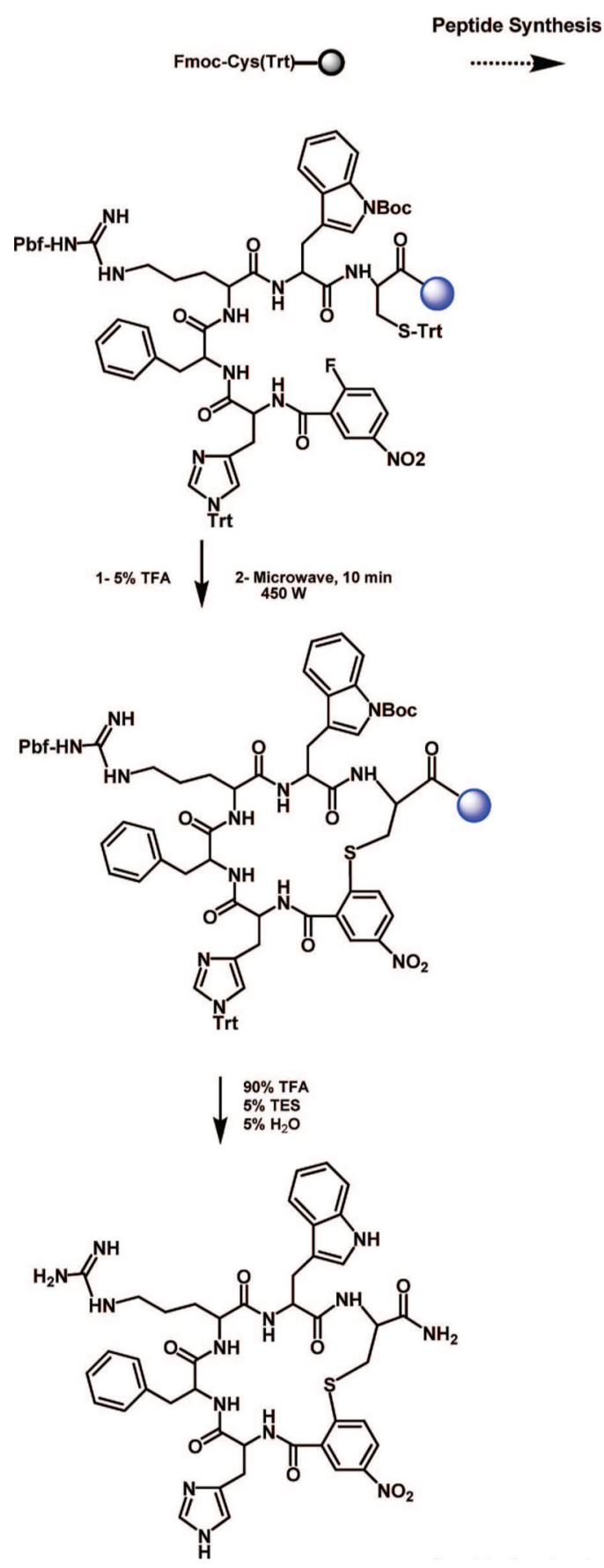

Scheme 1.

General Synthetic Method for Macrocyclic Melanocortins 

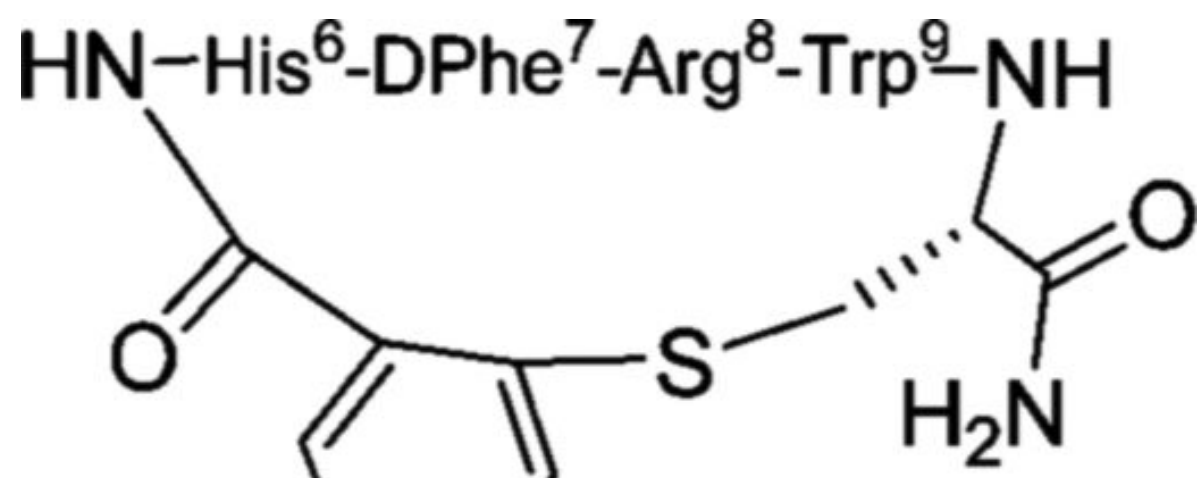<smiles>C1CCCCC1</smiles>

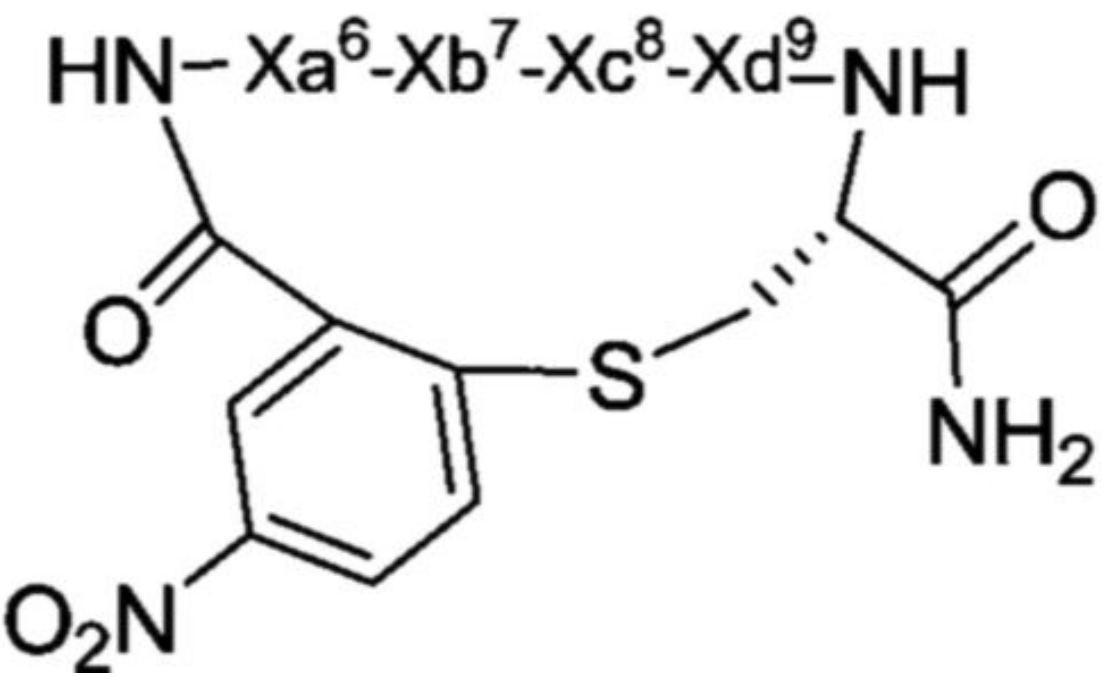

Figure 1.

Design of macrocyclic compounds using $\mathrm{L}_{\mathrm{L}} \mathrm{Cys}$. 

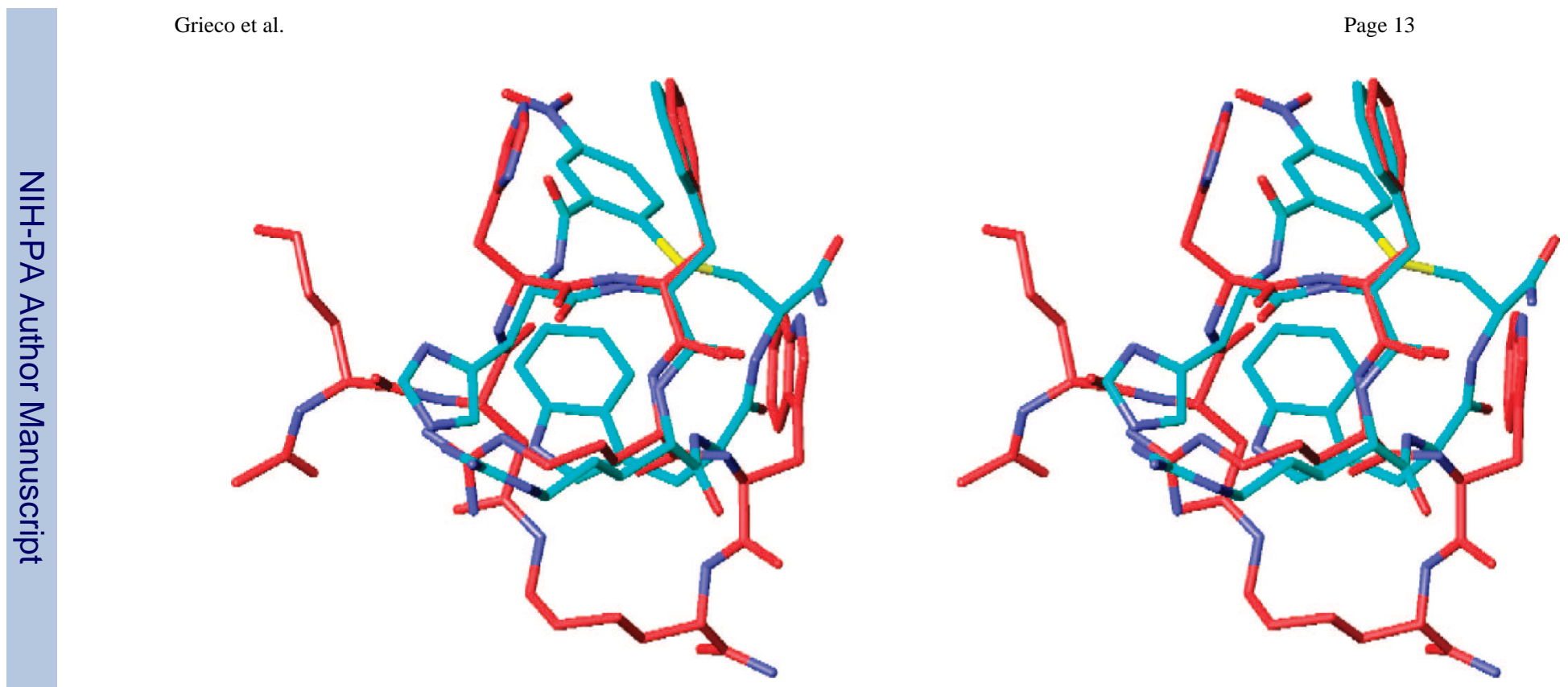

Figure 2.

Stereoview of the superimposed NMR structure of MTII (red) with MCMM/LMCS-OPLS 2005-derived structure of $\mathbf{1}$ (blue). 

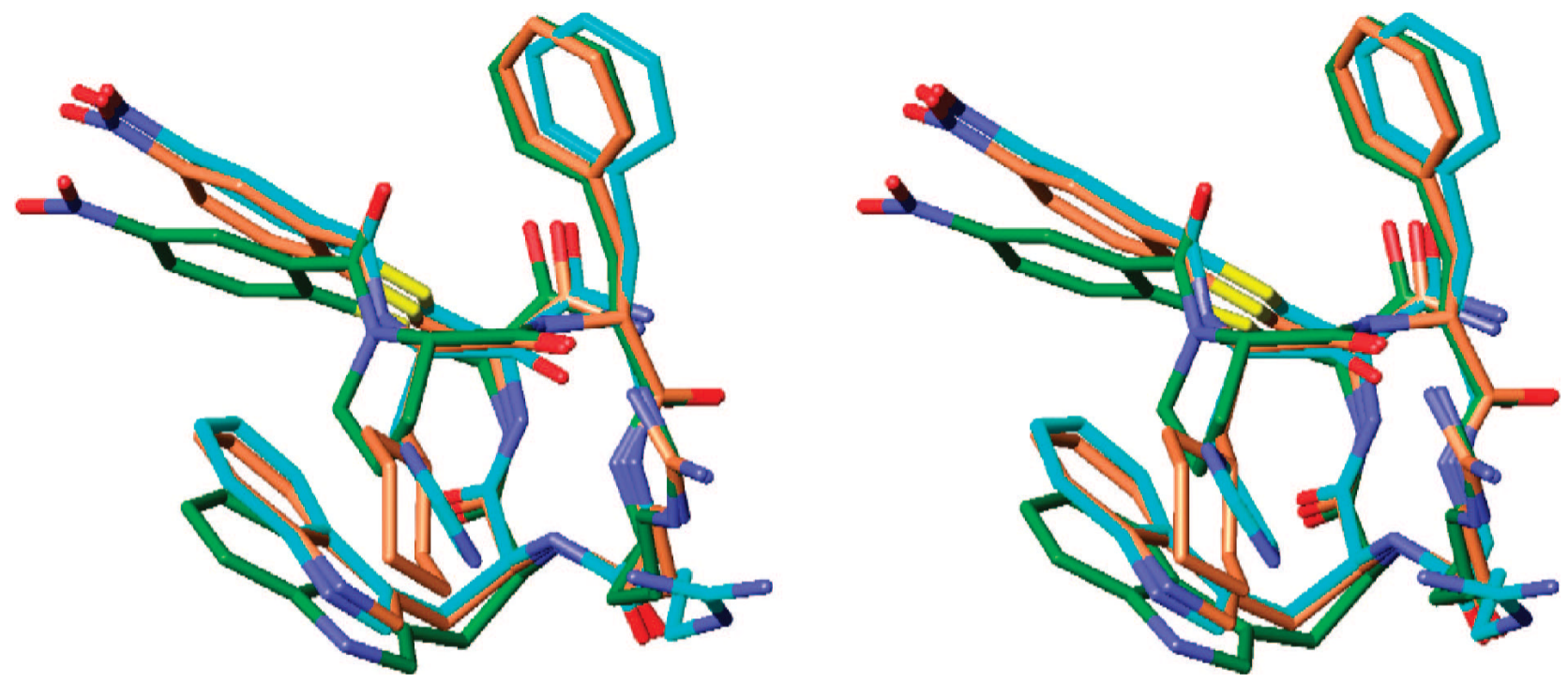

Figure 3.

Stereoview of the superimposed MCMM/LMCS-OPLS 2005-derived structure of peptide 4 (orange), $\mathbf{7}$ (green) and $\mathbf{1}$ (blue). The aromatic linker is highly stacked with the indole ring of Trp 9 . This caused the peptide to adopt a new conformation favorable to hMC5R binding. 

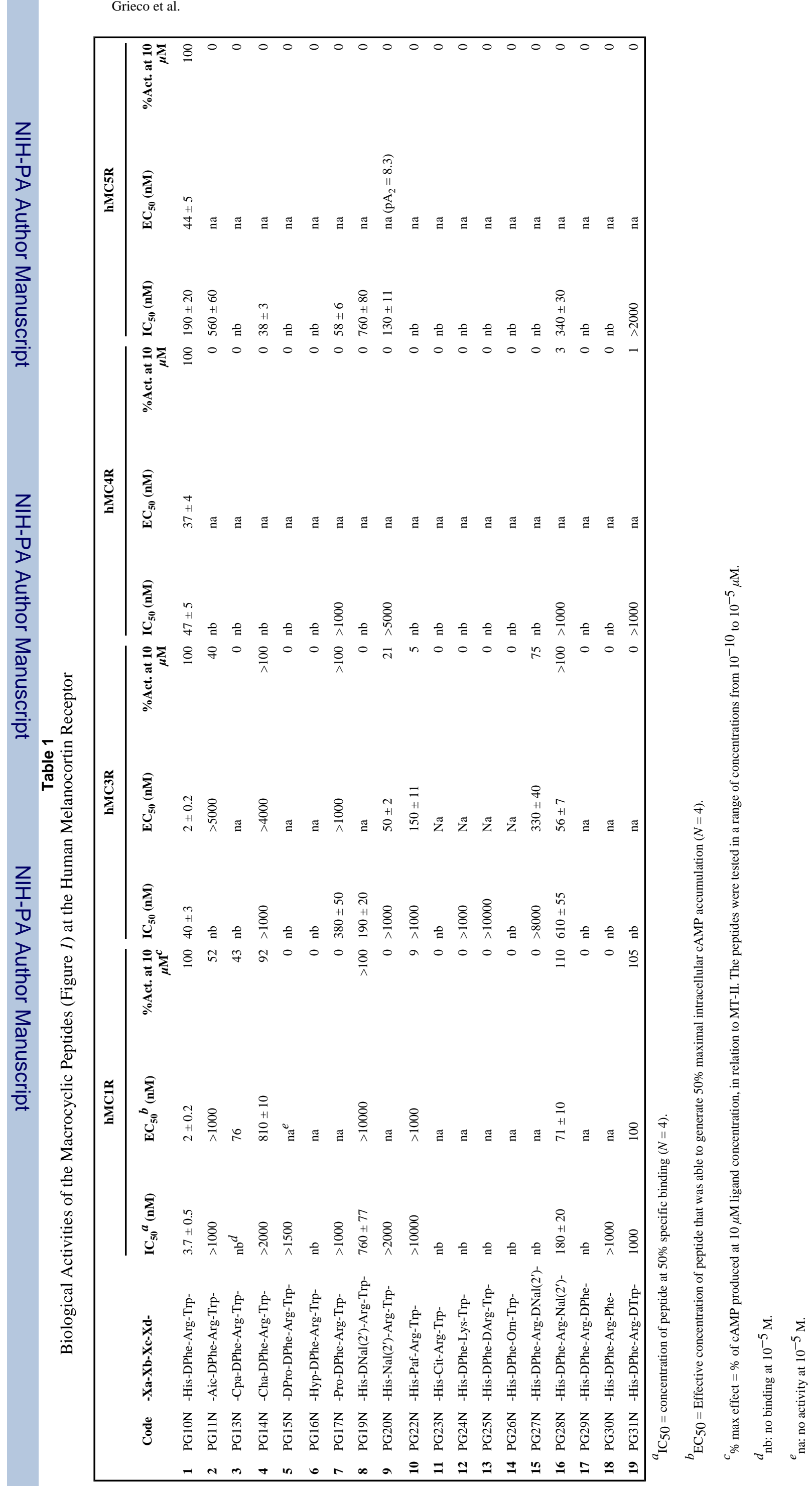


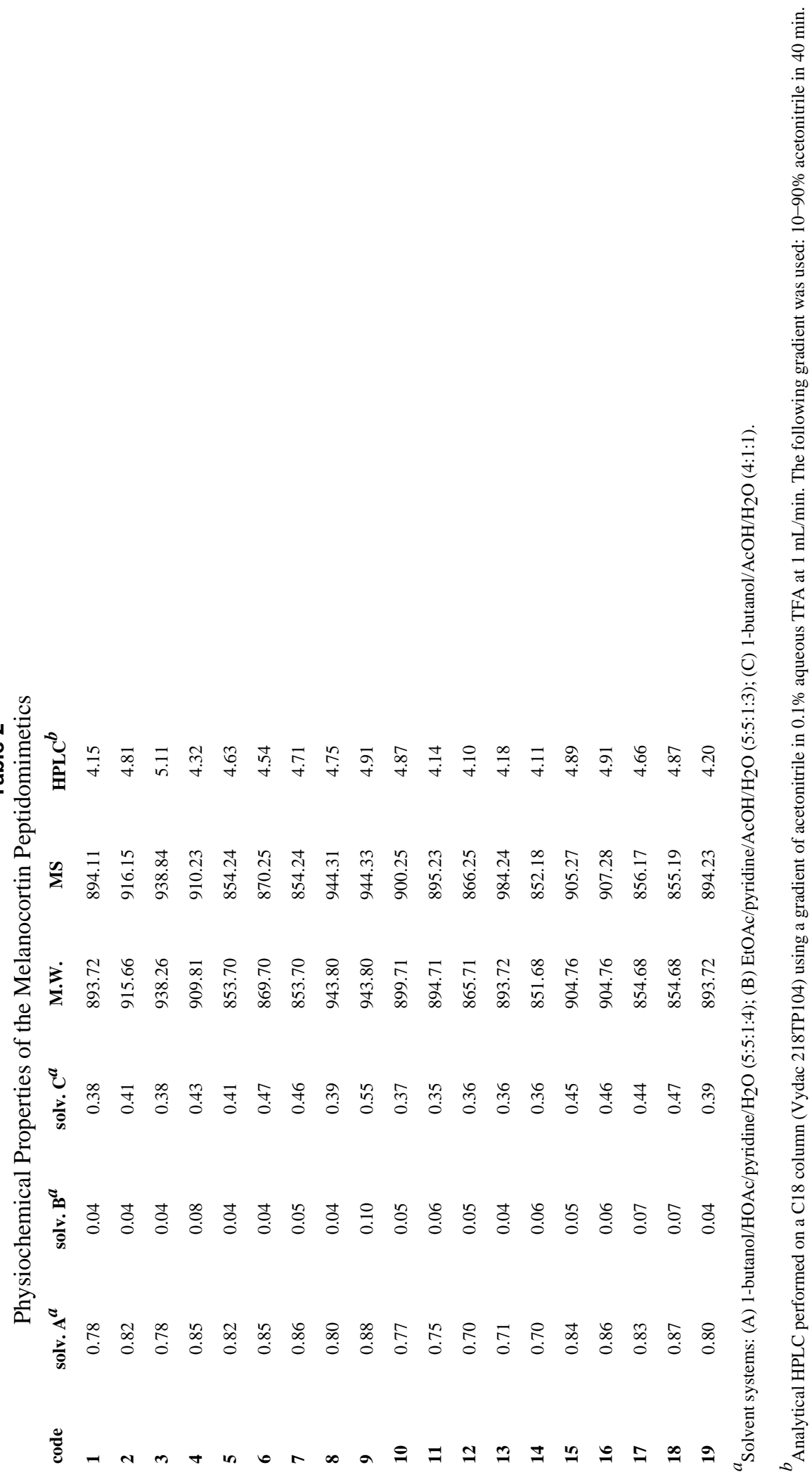

